\title{
RETORIK IKNA BILEŞENLERIN SIYASI LIDERLERCE KULLANIMI: IKTIDAR VE ANA MUHALEFET LIDERLERININ TBMM GRUP KONUŞMALARI ÜZERINE BIR ANALIZ
}

Murat BAŞARIR $^{1}$

\begin{abstract}
öz
İkna, siyasal iletişimin ilgilendiği temel konulardan birisidir. Şüphesiz ki retorik prensipler çerçevesinde siyasi parti liderleri tarafından icra edilen konuşmalar ikna edici ifadeleri barındırmaktadır. Bu çalışma, retorik ikna bileşenlerinin iktidar ve ana muhalefet partisi liderlerince kullanılma yoğunluklarına yönelik dönemsel bir kesit sunmayı amaçlamıştır.

$\mathrm{Bu}$ amaç doğrultusunda iktidar ve ana muhalefet partisi liderlerinin 14, 21 ve 28 Haziran 2016 tarihlerinde TBMM grubunda gerçekleştirdikleri konuşmalar içerik analizine, analiz neticesinde elde edilen veriler ise Ki-kare testine tabi tutulmuştur. Araştırmada, liderlerin grup konuşmalarında ele aldıkları temalarda ve temalarda kullandıkları ikna bileşenlerinin yoğunluklarında farklılıklar tespit edilmiştir. Diğer yandan özellikle liderlerin konuşmalarında değindiği ortak temalara bakıldığında ise kullandıkları ikna bileşenleri arasında anlamlı ilişkiler bulunmuştur. Buna göre ele alınan ortak temalarda, ethos (kaynağın güvenilirliği) ve pathos (duygusal çekicilikler) ikna bileşenlerinin iktidar partisi liderince, logos (rasyonel çekicilikler) ikna bileşenin ise ana muhalefet partisi liderince daha yoğun kullanıldığı tespit edilmiştir. Çalışma, iktidar partisi liderliğindeki değişimle ortaya çıkan yeni siyasal iklimde gerçekleştirilmesi ve ilgili liderlerin retorik performanslarına odaklanan ilk çalışmalardan olması münasebetiyle benzerlerinden ayrılmaktadır.
\end{abstract}

Anahtar Kelimeler: Siyasal iletişim, ikna, retorik, siyasi lider, TBMM grup konuşmaları

\section{USE OF RHETORICAL PERSUASION COMPONENTS BY POLITICAL LEADERS: AN ANALYSIS ON THE GROUP SPEECHES PERFORMED BY THE RULING AND THE MAIN OPPOSITION LEADERS IN TGNA \\ ABSTRACT}

Persuasion is one of the main topics which political communication is interested in. Doubtlessly, the speeches which are performed by political party leaders based on the rhetorical principles are composed of persuasive expressions. This study aims to present a periodical segment in terms of the intensity of the use of the rhetorical persuasion components by the ruling and main opposition party leaders.

Accordingly, the speeches which were performed by the ruling and the main opposition party leaders on June 14, 21, and 28 in TGNA were subjected to content analysis and the results of this analysis were tested with $\mathrm{Ki}$-square tests. In the study, it is identified that there are differences between the themes the leaders made use of in their speeches and between the intensities of the persuasion components they used in these themes. On the other hand, when the common themes the leaders used in their speeches are given a special attention, it is

${ }^{1}$ Öğr.Gör.Dr., Harran Üniversitesi, Birecik MYO, muratbasarir@harran.edu.tr 
observed that there are meaningful relations among the persuasion components they used. As a result, it is found out that the ruling party leader made use of ethos (source reliability) and pathos (emotional attractions) and the main opposition leader made use of logos (rational attractions) more intensely. This study differs from the similar studies in respect that it is conducted in the new political climate which emerged after the change in the ruling party leadership and it is one of the first studies which focus on the rhetorical performances of the aforementioned leaders.

Keywords: Political communication, persuasion, rhetoric, political leader, TGNA group speeches

\section{Giriş}

Uzunca bir süredir siyasetin iletişime bağımlılığı, siyaset bilimcilerce kabul edilmektedir. Ayrıca iletişimin farklı tiplerinin ve seviyelerinin varlığına dikkat çekilerek iletişim sistemiyle siyasal sistemin birbirine paralellik gösterdiği ileri sürülmektedir (Roskin vd., 2013: 186). Bu bağlamda, iletişimsel ya da siyasal olanın odağının güç olduğu ve gündelik pratikler söz konusu edildiğinde her ikisinin de esasında güç uygulaması gibi değerlendirilebileceği iddia edilmektedir (Erdoğan, 1997: 120). Başkalarına istediğini yaptırabilme gücü biçiminde tarifi yapılan "iktidar"ın siyasetin ana konusunu meydana getirdiği ve yine "iktidar" yerine etkileme, kontrol etme, hâkim olma ve yönetme kelimelerinin de duruma göre tercih edilebildiği vurgulanmaktadır (Türköne, 2014: 27, 49). Ilımlı uçtaki “etki” den, diğer uçtaki "zorlamaya" kadar uzanan bir yelpazenin tasavvurunu gerekli k1lan "ikna" (Jamieson, 1996: 4) siyasi iktidarın elde edilmesini ve sürdürülmesini sağlamada etkin bir rol üstlenmektedir. Yine ikna, tüm siyasal iletişim aktivitelerinin mesaj tasarım aşamasında her daim hesaba katılmaktadır.

Demokrasinin gelişmesi, seçimlerin ön plana çıkması, meşruiyetin değer kazanması vb. gelişmeler siyasal iletişim sürecinde iknanın önemini daha da artırmıştır. Artık siyasal iletişim, bireylerin destek ve güvenlerini kazanmak amacıyla yapılan halkla ilişsiler, reklam, propaganda gibi ikna gerçekleştirmeye yönelik yöntemlerin kullanılması biçiminde görülmektedir (Damlapınar ve Balcı, 2014: 33). Bu durum, siyasal iletişim sürecinde, mesajların daha profesyonelce hazırlanmasını beraberinde getirmektedir. Propaganda, halkla ilişkiler ve reklam gibi disiplinlerden elde edilen bilgiler yoğrularak, seçmenlerin karşısına, teknik altyapısı muazzam tasarlanmış mesajlarla çıkılarak seçmenler ikna edilmeye çalışılmaktadır. Ancak, 
mesaj üretimindeki tüm bu profesyonelleşmeye, mesajların farklı medyalarla sunulma imkânının artmasına rağmen, her zaman siyasetin politik konuşmalar üzerinden yürütüldüğünü de akıldan çıkarmamak gerekmektedir. Retorik geçmişten bugünlere gelinceye kadar varlığını sapasağlam bir biçimde korumayı başarmıştır (Başarır, 2015: 3).

Her türlü iletişimin asli karakteri olarak karşımıza çıkan retorik (Uzun, 2015: 34), Fidan'ın belirttiği gibi (2000: 46), kampanyalarda seçmenlerin bağlılığını ve siyasi temsillerin sunumlarının meşruiyetini sağlamak için kullanılmaktadır. Günümüzde bazı kamuoyu yoklamaları neticesinde seçmenlerin parti tercihlerinde birinci derecede önemli etken konumunda bulunan liderler de (Doğan ve Göker, 2013: 29) retorik bileşenler çerçevesinde muhtelif (açılışlar, davetler, açıklamalar, mitingler vb) konuşmalar gerçekleştirmektedirler. Siyasi liderlerin farklı gayelerle yaptıkları konuşmalarının içerisinden periyodiklik gösterenlerinden birisi de salı günleri TBMM'de gruplarının karşısında gerçekleştirdikleri konuşmalardır ve gündem oluşturma ile kamuoyuna yansıtılma açısından ülkemizde dikkat çeken bir siyasal iletişim uygulamasıdır.

Güncel siyasi konuşmalar ve tartışmalar, liderlerin yeteneklerinin algılanmasında ve değerlendirilmesinde seçmenleri geliştirebilmektedir (Catellani vd., 2013: 77). Seçmenlerin karar alma sürecinde, durum tespitinde ve alternatiflerin seçilmesinde etkili olabilmektedir. Konuşmaların seçmenlerin karar alma süreçlerindeki bahsedilen etkisinden dolayı bu çalışma, iktidar ve ana muhalefet partisi liderlerinin parti gruplarına periyodik şekilde gerçekleştirdikleri hitaplarını araştırma materyali olarak seçmekte ve seçilen konuşmaları retorik ikna bileşenleri boyutundan içerik analizine tabi tutmaktadır. Böylece iktidar ve ana muhalefet liderlerinin aynı gün ve benzer özellikler barındıran toplantılarda söylemlerinden hareketle retorik içerisindeki ikna bileşenlerini kullanma yoğunluklarına ilişkin dönemsel bir kesit sunmayı amaçlamaktadır. Bu maksatla çalışma;

i. İktidar ve ana muhalefet liderlerinin konuşmalarında ele aldıkları konulara bağlı bir şekilde ikna bileşenleri değişmekte midir?

ii. İktidar ve muhalefette bulunmaya bağlı olarak konuşmalarda ikna bileşenleri açısından bir farklılık gözlenmekte midir? 
iii. İktidar ve ana muhalefet liderlerinin ele aldıkları ortak temalar açısından ikna bileşenlerinde bir yoğunluk farkı bulunmakta mıdır?

iv. Liderlerin konuşmalarındaki üslup farklarına bağlı olarak ikna bileşenleri biçimlenmekte midir? Araştırma soruları üzerinden gerçekleştirilmiştir.

\section{Iletişim, íkna ve Siyaset}

İnsan ve toplum yaşamının sistemli yapılara dönüştürülmesinin önemli bir aracı konumundaki iletişimin sistematik yapısı içerisinde insanlar, birbiriyle anlaşabilme, bağlantı kurabilme, yaşama ilişkin gelişmeleri düzenli kayıtlara dönüştürebilme ve yapıp ettiklerini kuşaktan kuşağa aktarabilme imkânını elde etmişlerdir. Böylece ortaklık kültürünü geliştiren iletişim, toplumsal bir bütün olmanın temel öncülü sayılmıştır (Güngör, 2011: 36-37). Bu öncüllüğün izdüşümü davranışla iletişimi eş değer gören Watzlawick ve arkadaşlarının “iletişimsizlik mümkün değildir” temel varsayımında da (Gökçe, 1993: 29) bulunabilir. Bu öncül ve varsayımdan hareketle ise insanların devamlı surette iletişim sürecine bir takım amaçlarını gerçekleştirmek için dâhil oldukları söylenebilir.

Bilgi alışverişi, yardım talebi, emir vermek, söz vermek, eğlence sağlamak, kendi fikirlerini anlatmak, vb bahsi geçen amaçlardan sadece bazılarıdır. Tüm bu amaç yelpazesinin genişliğine rağmen esasında en basit bir diyalogun bile ikna etme ile bağlantısından rahatlıkla bahsedilebilir. Nitekim Yavaşgel (2004: 1), iletişimin özünde bilgi iletmenin de ötesinde ikna etme ve etkilemenin bulunduğunu aktarmakta; Jamieson ise (1996: 5) niyet tarafı çıkartıldığında ikna kuramının iletişim kuramı ile ortak bir zemini paylaştıklarının gözlemlendiğine dikkat çekmektedir. Anık ise (2000: 35) bilinçli girişim, davranış değişikliği ya da motivasyon veya manipülasyon ortaya çıkartabilmenin aracının iletişimden geçtiğini vurgulamaktadır. Yine bundan dolayı ikna konusunun, büyük ölçüde iletişimin inceleme alanı olarak ortaya çıktığının altını çizmekte ve iknayla alakalı tüm tanımların ortak paydasının iletişim olduğunu belirtmektedir. Öyleyse iletişimle doğrudan rabıta içerisindeki ikna "davranışların, niyetlerin, duyguların, kanaatlerin değiştirilmesi ya da değiştirilmemesine yönelik iletişim unsurlarından yararlanılan psikolojik bir süreç”i tanımlamakta ayrıca bünyesinde bilinçli niyet, davranış değiştirme ve mesaj nakli şeklinde üç boyutu barındırmaktadır (Özkan, 2004: 156- 
157). İletişim olgusunun pek çoğunda insanlar birisini, davranışlarını değiştirmesi ya da davranış biçimini değiştirmesi için, ikna etmeyi amaçlamaktadır. (Yüksel, 1994: 3). Unutulmamalıdır ki, ikna çabaları ne kadar farklı görünüm kazanırsa kazansın, özünde bir iletişimsel eylem barındırmak zorundadır.

Öte yandan Jamieson'un vurguladığg gibi (1996: 206), ikna her ne kadar doğrudan bireyin kendisi ile bağlantılıysa da, bireyin diğer insanlarla olan varoluşuyla da ilgilidir. Bundan dolayı ikna süreci bireysel-toplumsal temelleri olan bir yapı içerisinde değerlendirilmekte, hatta ikna toplumsal denetim ve karş1lıklı uyumun sağlanması, kargaşanın önlenmesi için gerekli bir unsur telakki edilmektedir (Anık, 2000: 34). Öyle ki siyaset sahasında da yönetmek için ikna etmenin zorunluluğu ortaya çıkmakta yeteri kadar güç sahibi olunsa da, insanlar itaate mecbur olsa da ikna ederek yönetmenin en etkili ve sürekli çözüm olduğu ifade edilmektedir (Türköne, 2014: 220). Kalender de (2005: 122), seçmenlerin ikna edilmesinde asıl hedefin harekete geçirme olduğunu belirtmekte ve bunun da oy verdirme ve aday ile parti lehine çalışma yaptırmak manasına geldiğini ileri sürmektedir.

Değişen toplumsal ve siyasal koşullarla ilişkili olarak 'ikna' vasıtası ile 'rıza'nın yeniden üretilmesi çabaları, tarih boyunca toplumsal, ekonomik ve teknolojik gelişmelere bağlı olarak çeşitli görünümler kazanarak devam etmektedir (Taşcığlu, 2007: 25). Demokratik toplumsal yapılarda da siyasal ikna, siyasal iletişimin başlıca unsurlarından biri biçiminde karşımıza çıkmakta ve siyasal iletişim faaliyetlerinin temeli olarak, belirli bir kitleyi, zor kullanmaksızın manipüle etmek, oy verme davranışları üzerinde etki sağlamak amacıyla yürütülen bir süreci açıklamaktadır (Barut ve Altundağ, 2005: 80). Bu süreç, siyasal alanla ilişkili bütün değişkenlerin iletişim süreciyle girdiği bir etkileşim olarak görülmeli (Damlapınar ve Balcı, 2014: 37) ve yalnızca seçim kampanyası dönemiyle sınırlı değerlendirilmemelidir (Balc1, 2003: 158). Siyasetin yürütüldüğü tüm zamanlarda ve her türlü iletişim uygulamalarında siyasi aktörlerce, en başta siyasi liderler tarafından, göz ardı edilmeksizin doğru ilke ve teknikler kullanılarak işletilmelidir.

Aslında siyaset, kendine mahsus bir dil ile insanların kanaatlerini etkilemek, kanaati tesis edilmemiş olanları kanaat sahibi kılmak ve nihayetinde onları taraftarlar safına almak gayesini güder. Siyasete bu yönüyle yaklaşıldığında, kavramın sorun 
çözme sanatı olma karakterinden ziyade, yönlendirme yönüne ağırlık kazandırıldığı ifade edilebilir. $\mathrm{Bu}$ da siyaset sanatında kitleleri ikna etme becerisinin önemini açıklamaktadır (Akyüz, 2009: 95). Özkan da (2004: 18), benzer açılardan hareketle siyaset kurumunun iletişim olgusunu bir araç olarak gördüğünü ve amaçlarını gerçekleştirmek için iletişimsel eylemlerden faydalandığını belirtmekte ve siyasetin kendini ifade edebilme yolunun iletişim faaliyetlerinden geçtiğini söylemektedir.

Günümüzde seçim kampanyalarında iktidara talip olanların yönetilecek olanlara götürecekleri hizmetleri görünür kılınmasına duydukları gereksinim, hizmetlerin nasıl sunulacağı, herkesçe nasıl anlaşılabileceği, herkesin beğeni, arzu ve isteklerinin nasıl karşılayacağı üzerine yoğunlaşmalarını doğurmuştur. Bu yoğunluk da reklam ve halkla ilişkiler sektörünün herkese seslenebilir olma yolunda edindiği tecrübelerin, politik alana kaydırılmasıyla sonuçlanmıştır (Köker, 2007: 23). İkna çalışmalarına hangi açıdan yaklaşılırsa yaklaşılsın, mizah çekiciliği, cinsel çekicilik, mesaj tekrarı, korku çekiciliği ve kapıyı aralama gibi değişmeyen bazı teknikler kullanılmaktadır (Kalender, 2005: 126).

Reklam ve halkla ilişkiler uygulama alanlarındaki teknikler seçim kampanyalarının hazırlanılmasında ve uygulanmasında sıklıkla kullanılmasına karşın politikacıların konuşmaları her daim temel iletişim yöntemi olarak siyasal iletişimde varlığını sürdürmüştür. Köker de (2007: 81, 84) Aristoteles'in politika yapma tarzının dolayımsız aracı konuşma halini politikanın kendisi, diyalektiğin eşdeşi şeklinde tanımladığından hareketle iletişimsel olan ile politik olanın birliğine gönderme yaptığını ifade etmektedir. Hatta politik iletişimin tümüyle politik konuşmalardan ibaret olduğu yönünde bir eğilimin varlığına dikkat çeker. Hülasa bir iletişim tekniği olan politik konuşma siyasal iletişimin ilgilendiği temel konularından birisidir ve politik konuşmaları kavrayabilmek için retorik sanatının öğretilerine bakılması gerekir.

\section{Bir Siyasal İkna Enstrümanı Olarak Retorik}

Dünyanın en eski disiplinlerinden biri olma sıfatıyla retorik, karşıdaki kişiyi kendi çıkarları doğrultusunda ikna etmek uğruna güzel konuşma çabasıdır ve ikna sanatı olarak retoriğin doğuş dönemlerindeki amacı, toplumsal yaşamda rol üstlenen 
konuşma şekillerini, muhatabını etkileyecek şekilde, önceden planlayarak etkili bir sunuma dönüştürmektir (Tepebaş11, 2016: 16). Nitekim Aristo da retoriği "belli bir durumda elde var olan inandırma yollarını kullanma yetisi” şeklinde tanımlamakta; törensel, adli ve politik olmak üzere üç türü bulunduğunu söylemektedir (2008: 37, 43).

Çalışmamız açısından ilgilenilen tür ise politik retoriktir. Politik retorik, hatip tarafından bir eylem yolunun uygunluğunun ya da zararlı olduğunun tanıtılmasının amaç edinildiği bir tür olarak değerlendirilmektedir (Aristotales, 2008: 44). Politik retorik, dinleyicilere bir şey yapmaya ya da yapmamaya dönük önerilerin mevcut olduğu bir yapıya sahiptir ve davranışsal bir eylem sürecini destekler bir niteliktedir (Polat, 2008: 87). Bu retorik türün bölümlerini, cesaretlendirme ve umut kırma meydana getirmekte, zaman boyutunda geleceğe işaret edilmekte, sonuçlarında ise uygunluk ve uygunsuzluk üzerinde durulmaktadır (Aristotales, 2008: 20). Tepebaşılı'nın (2016: 40) konuşmaların türü, muhatabı, işlevi, zamanı ve amacı bağlamında yaptığı tabloya bakıldığında politik konuşma; meclis ve mitinglerde muhatabını halk olarak alan, fayda ve zararı amaç edinen, gelecek zaman perspektifinde tavsiye işlevi gören bir yapı sunmaktadır. Bu yapı içerisinde bütün insanların üzerinde düşündüğü, politik söylevcilerin üzerinde konuşmalar yaptığı ana konular beşli bir tasnif altında açıklanmaktadır (Aristotales, 2008: 44). Bu tasniflenmiş konuşma alanlarının ilki “yollar ve araçlar”dır. İkinci konuşma alanı “ savaş ve barış" a ilişkindir. Üçüncüsü ise "ulusal savunma" üzerine konumlandırılır. Dördüncü konu başlığı “dış alım ve dış satım” iken nihayetinde beşincisi ise “yasalar” üzerinedir. Günümüzde dahi bu konu başlıkları altında değerlendirilebilecek mesajlar siyasal iletişim sürecinde liderlerce seçmenlere sunulmaktadir.

Siyasal lider, siyasal topluluğun başında bulunarak, söz konusu topluluğu amaçları yönünde kanalize eden, üyelerin bireysel amaçlarıyla topluluk amaçlarını koordineli hale getiren ve üyelerde müşterek bir bilinç oluşturarak siyasal topluluğu yükseltme gayreti içerisindeki kişiler (Arklan, 2006: 48) olmaları nedeniyle mesaj tasarımına özel gayret göstermelidirler. Lider sunduğu mesajların hedef kitleler tarafından hedeflendiği şekilde algılanması için doğru propagandanın kalbindeki üç 
temel unsur olarak nitelenen mit, sembolizm ve retorikten (Lilleker, 2013: 224) elbette faydalanmalıdır. Çünkü siyasal iletişim sürecinde retorik iletişim: a) toplumsal bir ideoloji dâhilinde iktidarın dağılımını doğrulayarak onu meşru kılmakta, b) toplumu ortak hedefler temelinde yönlendirmekte, c) ortak hedefleri tanımlayarak çatışmaları sonlandırmakta ve d) aktivasyon ve organizasyonlar vasıtasıyla hareketlilik sağlamaktadır" (Lilleker, 2013: 250). Zaten lider de retorik iletişimin bu niteliklerine duyarsız kalamamakta öyle ki, Roma siyasal düşüncesine göre politikacıya yönetme gücünü veren önemli bir etken pozisyonundaki politik konuşma “ideal devlet adamının” ya da seçkin azınlıktan olanın kazanmakla yükümlü olduğu bir yetenek olarak görülmektedir (Polat, 2008: 115). Siyasi liderler bu yeteneklerini geliştirirken retorik sanatının tarihten bugüne kadar getirdiği birikimden faydalanmaktadırlar.

Nitekim didaktik ihtiyaçlardan ve konuşmacının kendisini daha iyi ifade edebilmesi için getirilen suni bir ayrım hüviyetindeki konuşma üretim basamakları (partes artis) olan, a) Buluş (inventio / heuresis), b) Düzenleme (disposito / taxis), c) Dillendirme (elocutio / lexis), d) Ezberleme (memoria/ mneme) ve e) Sunum, beden dili (actio veya pronuntiatio / hypokrisis) (Tepebaşı11, 2016: 26) gibi ikna bileşenleri üzerinden konuşmalarda dikkat edilecek hususlar sunulmaktadır.

\section{Retorik Illetişimde İkna Bileşenleri}

Y1lmaz (2007: 188), Larson'a atıfla iknanın simge/gösterge kullanımı neticesinde bir kaynak bir alıcı arasındaki özdeşleşme durumunun birlikte teşekkül ettirilmesiyle oluşacağını belirtmekte ve yalnızca kaynak ve alıcı arasında işbirliği meydana geldiğinde vücuda geleceğini aktarmaktadır. Böylece ikna, ikna eden ile edilen arasında ortak bir zeminin varlığı söz konusu olduğunda daha da etkin olabilmektedir. Bahsedildiği üzere iknanın gerçekleşmesi işbirliğine ve ortak zeminin teşekkül ettirilmesine bağlı olduğundan dolayı politik konuşmalarda siyasi liderler bu iki durumu konuşmalarında yansıtmalıdırlar.

Siyasi liderler zikredilen bu yansımayı Aristo'ya (2008: 38) göre, söylenen sözlerde bulunan üç inandırma tarzına bağlı kalarak gerçekleştirebilirler. Bahsedilen inandırma tarzlarından ilki konuşmacının kişisel karakterine bağlı olan ethos, ikincisi 
dinleyiciyi belirli bir ruh haline sokmaya bağlı olan pathos ve üçüncüsü ise sözcüklerin sağladığı tanıtlara bağlı olan logostur. Zikredilen bu üç bileşen politik konuşmalar içerisinde açık veya örtük bir yapıyla sunulmaktadır. Siyasi liderler de topluluklar karşısında icra ettikleri konuşmalarda bir takım dilsel araçlarla ikna bileşenlerini kullanmaktadırlar. Öyle ki liderlerin konuşmalarında bir şeyin nasıl söylendiği ne söylendiğinden daha önemli bir hale gelebilmektedir.

\section{a- Ethos (Kaynağın Güvenilirliği) :}

Aristo (2008: 38), bazı yazarlarca konuşmacının gösterdiği kişisel iyiliğin onun inandırma gücüne bir şey katmadığı düşüncesinin yanlışlığını dile getirmekte bilakis konuşmacının karakterinin sahip olacağı en etkili inandırma yolu olduğunu söylemektedir. Bundan dolayı retorik bir konuşmada, konuşmacı evvela ethosu sunmalıdır. Ancak dinleyiciler açısından bakıldığında ise, konuşmacının oluşturduğu ethos muhakkak sorgulanması gereken bir unsur biçiminde karşımıza çıkar (Ulaş, 2002: 501). Nitekim ethos özel bir yetkinlikten daha ziyade kişiye bağlıdır, konuşanın kendisi ile ilgili olarak verdiği ve kendisini dinlemeye ve izlemeye hazır dinleyicinin örnek aldığı imgesine bağlılık göstermektedir. Bundan ötürü, erdemler, doğru ve iyi tavırlar, güven duyma, güven verme konuşmayı gerçekleştirene bir otorite kazandırır (Meyer, 2009: 26). Bu otorite konuşan ile dinleyen arasındaki etkileşimin bir yorumuyla hayat bulur ve alıcılar nezdinde konuşmacıya yönelik yaratıcı bir izlenim içermektedir (Krostenko, 2004: 39). Bundan dolayı siyasi liderler yönetilenler nezdinde güven verici bir karakter taşıdıklarına yönelik çıkarım yapmalarına olanak sağlayan söylemler geliştirirler.

Kısaca ethos karmaşık biçimde yapılanmış konuşmada bir düzey, bir alan yani bir boyuttur ve genel olarak dinleyicinin özdeşleştiği biri gibidir (Meyer, 2009: 26). Bundan dolayı ethosa ilişkin konuşmayı gerçekleştirenin konuşmasıyla uyumu ve kişisel karakteri şeklinde bir bakış yaygınlık kazanmıştır (Çadırcı, 2010: 92). Bu minvalde konuya yaklaşıldığında liderlerin konuşmalarında kendisinin, partisinin, ideolojisinin karakterini yansitan ifadeler, kendisinin veya partisinin gerçekleştirdikleri başarılardan bahsetmesi, konuştuğu konu üzerinde tecrübe sahibi olduğunu belirtmesi, konuşmanın gerçekleştiği yere ve zamana uygun kelime 
seçimleri, dürüst tavır takındığını vurgulama vb. uygulamalar ethos bileşeni üzerinden ikna etme çabasının birer ürünüdür.

\section{b- Pathos (Duygusal Çekicilikler) :}

Pathos duygusal çekiciliklerin adıdır ve dinleyicinin psikolojik ve duygusal yanlarına bağlı olarak durumları anlamlandırmasının üzerinde durur. Aristo (2008: 38), mutlu ve dostluk duygularıyla dolu olduğumuz zamanlardaki yargılarımızın, sıkıntı içinde ve düşmanlık duygularıyla dolu olduğumuz zamanlardakilerle farklılığından yola çıkarak, bir konuşmada coşkular harekete geçirilmişse inandırmanın dinleyicilerden de gelebileceğini bildirmektedir.

Pathos; dinleyiciyi belli bir ruh haline sokmadır ve ethostan farklı olarak apriori (önsel) ve durağan değildir (Çadırc1, 2010: 92). Konuşmanın içerisinde şekil değiştirebilen bir öğedir. Anlaşılacağı üzere, Pathos'un hoşa giden istek ve tutkuları kapsayıcı bir yönü mevcuttur ve günümüzde psikolojik durumlar çatısı altında incelenen unsurlar pathos bileşeninin içerisinde değerlendirilmektedir (Yüksel, 2005: 22). Lauer (2004: 156) pathos sanatlı konuşmalarda konuşmacının seyircilerin tutumlarını, inançlarını ve deneyimlerini anlaması gerektiğini kaydetmektedir. Politik konuşmalar açısından patos değerlendirildiğinde liderlerin konuşma esnasında dinleyicileri belirli bir ruh haline kazandırmaya yönelik sarf ettikleri ifadeler bu kapsamda değerlendirilebilir. Konuşma sırasında kinlerin ortaya konulması, öfke barındıran nitelemeler, hamaset uyandıracak tabirler ya da neşe doğuracak söylemler, beraberlik vurgulayan ifadeler, destekçilerin çokluğunu dile getiren betimlemeler vb uygulamalar pathos bileşeni içerisinde değerlendirilebilir. Yüksel (2005: 22), aynı zamanda ethos olgusuyla da uygunluk göstermekle birlikte pathos boyutu çerisinde değerlendirilebilecek faziletli içerik oluşturan öğeleri adalet, sağduyu, cömertlik, cesaret, ölçülü olmak hoşgörü, nezaket ve akıllık/bilgelik şeklinde sıralamaktadır.

\section{c- Logos (Rasyonel Çekicilikler) :}

Retorik açıdan logos, iknada yer alan insanların, mantıki yeterlilikleri ile olay ve olgulara mantıklı bakışları ile ilişkili değerlendirilmektedir (Yüksel, 2005: 22). Bu ilişki neticesi ile gerçekleşecek bir iknada, inanmanın konuşmanın bizzat kendisi ile gerçekleşeceği söylenmektedir (Aristotales, 2008: 38). Bu yönü ile ne kaynağa 
yönelik göndermeler ne de duyguya yönelik göndermelere dikkat çekilmez. Mesajın kendi içerisinde ürettiği kanıtlar konuşmada vücut bulan sorulara kaynaklık etmektedir. İkna sürecinde ethosta kaynak, pathosta dinleyici ön plana çıkarken logosta dikkatler daha çok mesajın yapısına yönelmektedir.

Meyer (2009: 31), logosun soruları ve cevapları farklılıkları göstererek açıklayabilmesi gerektiğini söyler. Böylelikle, ikna edici iletişim eyleminde bulunan kişi, aslında büyük oranda, dinleyicinin bilgi sürecini en mantıksal yolla değerlendirip, karar verme yeteneğine güvenecektir (Yüksel, 2005: 22). Akla uygun aldığı kararlar ile dinleyicinin belleğinde tesir meydana getirilmesi amaçlanmaktadır.

Netice itibari ile konuşmacının, konuşma esnasında düşüncelerini destekleyecek güçlü materyallere ihtiyaç hissetmesi kaçınılmaz bir gerçekliktir. $\mathrm{Bu}$ ihtiyacını karşılayabilmek için ise konuşmacının karşısına; kanıtlardan, mukayeseli anlatımlardan, örneklerden faydalanabileceği bir yöntem çıkacaktır. Lauer (2004: 155) de, logosun kıyaslama yapmayı ve örneklerle anlatımı içerdiğini belirtmektedir. Siyasi liderlerin gerçekleştirdiği konuşmalarda, yer verdikleri rakamsal ifadeler, karşılaştırmalı anlatımlar, örnek göstererek icraatların aktarılması, gerekçe sunan bağlaçlarla yapılan ve ya yapılmayanların anlatılması vb uygulamalar logos ikna bileşeni perspektifinden değerlendirilebilir.

\section{Yöntem}

İktidar ve ana muhalefet partisi liderlerinin konuşmalarında kullandıkları ikna bileşenlerinin yoğunluğu üzerinde bir kesit sunmak üzere yapılan bu araştırmada, nitel araştırma tekniklerinden içerik analizi uygulanmıştır. İçerik analizine esas olan veriler, iktidar ve ana muhalefet partisi liderlerinin 14, 21 ve 28 Haziran 2016 tarihlerinde TBMM parti grubunda yaptıkları konuşmalardan temin edilmiştir.

Bu konuşmaların seçilmesi, 22 Mayıs 2016 tarihinde iktidar partisi genel başkanlığında yaşanan değişim neticesinde ortaya çıkan yeni siyasal iklime ilişkin ilk grup toplantıları olma önemlerinden kaynaklanmaktadır. Ayrıca liderlerin kamuoyuna yansıyan güncel konulara değinme gerekliliklerinden hareketle, konuşmalarda ortak temaların tespit edilebileceği mümkün görülmekte ve böylece mukayese yapmaya uygun bir veri sunacağı değerlendirilmektedir. İlaveten 
Türkiye'de TBMM grup toplantılarının retoriğin etkin kullanıldığı bir siyasal iletişim mecrası olma niteliği taşıdığının düşünülmesi çalışmanın belirlenen bu konuşmalar üzerinden yapılmasını sağlamıştır.

Liderlerin gerçekleştirdiği bu konuşmalardan toplamda 1772 cümle içerik analizine tabi tutulmuştur. Söz konusu cümlelerin 1143 tanesi ana muhalefet partisi liderine, 629 tanesi ise iktidar partisi liderine aittir. Hemen belirtmek gerekirse iktidar ve ana muhalefet liderlerinin konuşmalarındaki cümle kurma yapılarındaki üslup farklılıkları ve konuşmaya ayırdıkları süre başkalıkları analiz yapılan cümlelerin sayısal farkını fazlalaştırmaktadır.

Araştırmanın veri kaynağı olan ilgili konuşma metinleri cümlelere ayrıldıktan sonra her cümlenin hangi konuyla ilgili olduğu kodlanmış ve böylece konuşmalarda ele alınan temalar belirlenmiştir. Konuşmalardaki temalar belirlendikten sonra, konuşma metnindeki cümlelerin ethos (kaynağın güvenilirliği), pathos (duygusal çekicilikler) ve logos (rasyonel çekicilikler) ikna bileşenleri açısından hangisinin bünyesinde kodlanacağı ilgili alan yazındaki teorik bilgiler göz önünde tutularak değerlendirilmeye alınmıştır.

Söz konusu değerlendirmeler yapılırken tüm soru cümleleri, soru cümlelerine verilen cevapların olduğu cümleler, örneklerin sunulduğu cümleler, rakibin veya bir başkasının sözünü referans alarak kurulan cümleler, mukayese ihtiva eden cümleler, rakam barındıran cümleler, kanıt sunan cümleler, örnek barındıran cümleler, çünkü, bundan dolayı vb bağlaçlarla açıklama yapılan cümleler logos (rasyonel çekicilikler) ikna bileşeni içerisinde kodlamaya tabi tutulmuştur. Konular arasında geçiş sağlayan cümleler, sloganlaşmış ifadeler barındıran cümleler, deyimler ve atasözleri ile süslenmiş ifadelerin ön plana çıktığı cümleler, metaforik kullanım içeren cümleler, vicdanlı olmaya, ortak tavır takınmaya çağıran, beraberliği vurgulayan cümleler, suçlama, nükte, ironi, yüceltme, abartıyı doğrudan aktaran cümleler, tebrikler, dualar, dilek ve temenni cümleleri ise pathos (duygusal çekicilikler) ikna bileşeni içerisinde kodlanmıştır. Kararlılık, cesaret, meydan okuma barındıran cümleler, daha önce uyarı yapıldığını aktaran cümleler, irade beyan eden cümleler ile partinin, teşkilatın çalışkanlığını aktaran cümleler ise ethos (kaynağın güvenilirliği) bileşeni dâhilinde kodlanmıştır. Yapılan kodlamalar neticesinde bazen bir cümle aynı anda farklı ikna 
bileşenleri içerisinde de kodlanabildiğinden dolayı analiz iktidar partisi liderinin cümlelerine ait 724; ana muhalefet liderinin cümlelerine ait 1244 toplam 1968 item üzerinden yapılmıştır.

Öte yandan yapılan tematik kodlama sonucunda her iki lider için 5'i ortak olmak üzere toplam 7 tema tespit edilmiştir. Tespit edilen bu 5 ortak temadan başkanlık temasında iktidar partisi liderinin, selamlama ve kutlama temasında ise ana muhalefet partisi liderinin itemlerin azlığından dolayı bu iki tema mukayesede değerlendirme dışı bırakılmıştır. Nihayetinde iktidar ve ana muhalefet partisi liderlerinin konuşmalarındaki ikna bileşenlerini kullanma yoğunluklarının karşılaştırılması dış politika, terör ve ekonomi ortak temaları üzerinden gerçekleştirilmiştir. Bahsi geçen ortak temalar ile ikna bileşenleri ve parti liderleri arasındaki ilişkiyi ölçmek için ise Ki-kare analizi uygulanmıştır.

\section{Bulgular ve Yorum}

Tematik kodlamaların tasnifi neticesinde iktidar partisi liderinin konuşmaları terör, dış politika, ekonomi, icraat ve partiyi yüceltme, kutlama ve selamlama, başkanlık sistemi ve yasama faaliyetleri altında 7 temaya indirgenmiştir (Tablo 1).

En fazla temas ettiği temalara bakıldığında ekonomi ile icraat ve partiyi yücelten temaların öne çıktığı görülmektedir. Bu iki temayla ilgili cümleler birlikte değerlendirildiğinde \%41,3'lük bir orana ulaşmaktadır. Ekonomi, rasyonel çekicilik ikna bileşeninde \%59,60 oranıyla bu bileşenin en yüksek oranda kullanıldığı tema olurken; icraat ve partiyi yüceltme temasında ise kaynağın güvenirliliği ikna bileşeninin en yüksek kullanıldığı görülmektedir. Duygusal çekicilikler ikna bileşeninin ise \%69,79'luk oldukça yüksek bir oran ile kutlama-selamlama temasında kullanıldığg belirlenmiştir. Bu veriler bir arada değerlendirildiğinde iktidar partisi liderinin Haziran ayı grup konuşmalarında icraat ve parti başarıları teması üzerinden ethos bileşenini tesis ettiği, ekonomi temasında logos bileşeni kullandığı ve kutlama ve selamlama temasında ise pathos bileşenini kazandırmaya yönelik bir ikna stratejisi izlediği söylenebilir. Yine logos ikna bileşeninin dış politika temasında \%56’lık oranından hareketle; iktidar partisi liderinin dış politika konularını mukayeseli 
cümlelerle, izah üzerine inşa edilmiş cümlelerle ve tarihten alınan örneklerle sunmasının etkili olduğu değerlendirilmektedir.

Tablo 1. İktidar Partisi Liderinin Grup Konuşmalarında Ele Aldığı Temalar ve Bu Temalar Bağlamında Retorik İkna Bileşenlerinin Oranları

\begin{tabular}{|c|c|c|c|c|c|c|c|c|}
\hline \multirow[b]{2}{*}{ TEMALAR } & \multicolumn{2}{|c|}{ ETHOS } & \multicolumn{2}{|c|}{ PATHOS } & \multicolumn{2}{|c|}{ LOGOS } & \multicolumn{2}{|c|}{ TOPLAM } \\
\hline & $\mathbf{N}$ & $\%$ & $\mathbf{N}$ & $\%$ & $\mathbf{N}$ & $\%$ & $\mathbf{N}$ & $\%$ \\
\hline $\begin{array}{l}\text { TERÖR } \\
\text {-Yaşanan terör hadiselerini anlatan, açıklayan } \\
\text { cümleler } \\
\text {-Şehit yakınları ve gazilere yönelik kurulan } \\
\text { cümleler } \\
\text {-Şehit cenaze törenlerinde yaşanan olaylar }\end{array}$ & 28 & 22,58 & 54 & 43,55 & 42 & 33,87 & 124 & 17,13 \\
\hline $\begin{array}{l}\text { DIŞ POLiTiKA } \\
\text {-Türkiye ile Rusya, Avrupa Birliği, Almanya, İsrail } \\
\text { arasındaki ilişkilerle bağlantılı cümleler, } \\
\text {-Suriyeli mültecilerle ilgili cümleler } \\
\text {-Kıbrıs konusu ile ilgili cümleler }\end{array}$ & 11 & 8,80 & 44 & 35,20 & 70 & 56,00 & 125 & 17,27 \\
\hline $\begin{array}{l}\text { EKONOMi } \\
\text {-Tarım, hayvancılık ve turizm sektörüyle ilgili } \\
\text { cümleler } \\
\text {-Genel ekonomik yapıya ilişkin cümleler }\end{array}$ & 11 & 7,28 & 50 & 33,11 & 90 & 59,60 & 151 & 20,86 \\
\hline $\begin{array}{l}\text { KUTLAMA-SELAMLAMA } \\
\text {-Ramazan Bayramı, Kadir Gecesi kutlama } \\
\text { cümleleri } \\
\text {-A Milli futbol takımı ve Avrupa şampiyonasına } \\
\text { yönelik cümleler } \\
\text {-Okulların tatil edilmesi ve eğitim camiasını } \\
\text { tebrik } \\
\text {-Dilek, temenni ve dualar } \\
\text {-Konuşmaya giriş ve konuşmayı bitirmeye } \\
\text { yönelik cümleler }\end{array}$ & 12 & 12,50 & 67 & 69,79 & 17 & 17,71 & 96 & 13,26 \\
\hline $\begin{array}{l}\text { ICRAAT ve PARTiYi YÜCELTME } \\
\text {-Gerçekleştirilen açılışlar, getirilen yenilikler, } \\
\text { sunulan hizmetlerle ilgili cümleler } \\
\text { - Parti yönetimine, teşkilata, lidere övgü }\end{array}$ & 46 & 31,08 & 68 & 45,95 & 34 & 22,97 & 148 & 20,44 \\
\hline BAŞKANLIK SISTEMI & 8 & 40,00 & 10 & 50,00 & 2 & 10,00 & 20 & 2,76 \\
\hline YASAMA FAALIYETLERI & 6 & 10,00 & 23 & 38,33 & 31 & 51,67 & 60 & 8,29 \\
\hline TOPLAM & 122 & 16,85 & 316 & 43,65 & 286 & 39,50 & 724 & 100,00 \\
\hline
\end{tabular}

Tematik kodlamaların tasnifi neticesinde ana muhalefet partisi liderinin konuşmaları yönetim ve liyakat, başkanlık sistemi, öğrenci olayları, dış politika, ekonomi, terör, selamlama-kutlama altında 7 temaya indirgenmiştir (Tablo2).

Ana muhalefet liderinin en fazla değindiği temaların sırasıyla ekonomi ve dış politika olduğu gözlenmektedir. İki konu birlikte ele alındığında \% 61,98'lik bir orana ulaşmaktadır ve iki temada da rasyonel çekicilik ikna bileşenin tema içi oranı \%50'nin üzerinde tespit edilmiştir. Duygusal çekicilikler ikna bileşenine bakıldığında 
öğrenci olayları temasındaki \%64,29'luk oran dikkat çekmektedir. Kaynağın güvenilirliği ikna bileşeninin ise ekonomi ve başkanlık sistemi temasında en yüksek değerlere ulaştığı gözlenmiştir. $\mathrm{Bu}$ veriler bir arada değerlendirildiğinde; ana muhalefet liderinin Haziran ayı grup konuşmalarındaki ikna stratejisi, ekonomi ve dış politika temaları üzerinde logos öğrenci olayları temasında ise pathos ve başkanlık tartışmaları üzerinden ise ethos ikna bileşenlerini tesis etmek olduğu ifade edilebilir.

Tablo 2. Ana Muhalefet Partisi Liderinin Grup Konuşmalarında Ele Aldığı Temalar ve Bu Temalar Bağlamında Retorik Ikna Bileşenlerinin Oranları

\begin{tabular}{|c|c|c|c|c|c|c|c|c|}
\hline \multirow[b]{2}{*}{ TEMALAR } & \multicolumn{2}{|c|}{ ETHOS } & \multicolumn{2}{|c|}{ PATHOS } & \multicolumn{2}{|c|}{ LOGOS } & \multicolumn{2}{|c|}{ TOPLAM } \\
\hline & $\mathbf{N}$ & $\%$ & $\mathbf{N}$ & $\%$ & $\mathbf{N}$ & $\%$ & $\mathbf{N}$ & $\%$ \\
\hline $\begin{array}{l}\text { YÖNETIM VE LIYAKAT } \\
\text {-Adalet sistemi ile HSYK atamalarına } \\
\text { yönelik cümleler } \\
\text {-Kamuda yapılan görevlendirmelere } \\
\text { ilişkin cümleler } \\
\text {-Vatandaşların takınması gereken } \\
\text { tutumlarla ilgili cümleler }\end{array}$ & 10 & 7,46 & 60 & 44,78 & 64 & 47,76 & 134 & 10,77 \\
\hline $\begin{array}{l}\text { BAŞKANLIK SiSTEMi } \\
\text {-Cumhurbaşkanlığı yerleşkesi ile ilgili } \\
\text { cümleler } \\
\text { - Cumhurbaşkanın şahsına yönelik } \\
\text { kurulan cümleler }\end{array}$ & 13 & 12,87 & 47 & 46,53 & 41 & 40,59 & 101 & 8,12 \\
\hline $\begin{array}{l}\text { ÖĞRENCi OLAYLARI } \\
\text {-Bursa'da yaşanan hadise ile ilgili } \\
\text { cümleler } \\
\text {-Öğrenci olayları ile ilgili cümleler }\end{array}$ & 4 & 7,14 & 36 & 64,29 & 16 & 28,57 & 56 & 4,50 \\
\hline $\begin{array}{l}\text { DIŞ POLiTiKA } \\
\text {-Türkiye ile Rusya, Avrupa Birliği, } \\
\text { Almanya, İsrail arasındaki ilişkilerle } \\
\text { bağlantılı cümleler, } \\
\text {-Suriyeli mültecilerle ilgili cümleler } \\
\text { - Muhammed Ali'nin cenaze töreni ile } \\
\text { ilgili cümleler } \\
\text {-tutuklamalar ve Türkiye'nin } \\
\text { dışarıdaki imajı ile ilgili cümleler }\end{array}$ & 36 & 9,89 & 99 & 27,20 & 229 & 62,91 & 364 & 29,26 \\
\hline $\begin{array}{l}\text { EKONOMi } \\
\text {-Tarım, turizm sektörü ile ilgili } \\
\text { cümleler } \\
\text {-Kredi borçları ile ilgili cümleler } \\
\text { Aile sigortasına ilişkin cümleler EPK } \\
\text { ile ilgili cümleler }\end{array}$ & 54 & 13,27 & 119 & 29,24 & 234 & 57,49 & 407 & 32,72 \\
\hline SELAMLAMA- KUTLAMA & 2 & 33,33 & 4 & 66,67 & 0 & 0,00 & 6 & 0,48 \\
\hline $\begin{array}{l}\text { TERÖR } \\
\text {-Yaşanan terör hadiselerini anlatan, } \\
\text { açılayan cümleler } \\
\text {-Şehit yakınları ve gazilere yönelik } \\
\text { kurulan cümleler } \\
\text {-Şehit cenaze törenlerinde yaşanan } \\
\text { olaylar }\end{array}$ & 17 & 9,66 & 65 & 36,93 & 94 & 53,41 & 176 & 14,15 \\
\hline
\end{tabular}




\begin{tabular}{|r|l|l|l|l|l|l|l|l|}
\hline $\begin{array}{l}\text {-Terör örgütlerine mensup } \\
\text { mahkûmların hapishanede ziyaret } \\
\text { edilmesine yönelik cümleler }\end{array}$ & & & & & & & & \\
\hline TOPLAM & 136 & 10,93 & 430 & 34,57 & 678 & 54,50 & 1244 & $\begin{array}{l}100,0 \\
0\end{array}$ \\
\hline
\end{tabular}

Tablo 1 ve Tablo 2 beraber değerlendirildiğinde, konuşmalar içerisinde ekonomi teması, hem iktidar hem de ana muhalefet partisi liderlerince en yüksek oranda değinilen tema olarak tespit edilmiştir. Yine her ikisi tabloya göre logos (rasyonel çekicilik) bileşeni ekonomi teması içerisinde en yüksek düzeyde tespit edilmiştir. Bu durumun nedeni olarak, ekonomi temasında değinilen hususların diğer temalara kıyasla rakamlarla açıklanabilmesindeki kolaylıktan kaynaklandığı belirtilebilir. Yine tablolara birlikte bakıldığında; ana muhalefet partisi liderinin öğrenci olayları, iktidar partisi liderinin de kutlama ve selamlama temasında pathos ikna bileşenini yoğun kullandıkları görülmektedir. Çünkü pathos ikna bileşeni konuşmalarda coşkuyu yakalamak ve tabanda birliği sağlamak için liderlere uygun jargonu kullanabilecekleri bir zemin sunmaktadır.

Tablo 3. İktidar ve Ana Muhalefet Liderlerinin Ortak Ele Aldıkları Temaların İkna Bileşenleri Bağlamında Karşılaştırılması

\begin{tabular}{|c|c|c|c|c|c|c|c|c|}
\hline \multirow{2}{*}{\multicolumn{3}{|c|}{ Konular }} & \multicolumn{2}{|c|}{ Partiler } & \multirow{3}{*}{$\begin{array}{c}\text { Toplam } \\
47\end{array}$} & \multicolumn{3}{|c|}{ Pearson Kikare } \\
\hline & & & \multirow{2}{*}{$\begin{array}{c}\text { İktidar Partisi } \\
11\end{array}$} & \multirow{2}{*}{$\begin{array}{c}\text { Ana } \\
\begin{array}{c}\text { Muhalefet } \\
\text { Partisi }\end{array} \\
36\end{array}$} & & $x^{2}$ & $s d$ & $P$ \\
\hline \multirow{6}{*}{ 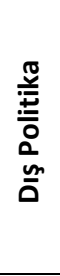 } & \multirow{2}{*}{ Ethos } & $\mathrm{N}$ & & & & \multirow{6}{*}{2,880} & \multirow{6}{*}{2} & \multirow{6}{*}{ 237 } \\
\hline & & $\%$ & 8,8 & 9,9 & 9,6 & & & \\
\hline & \multirow{2}{*}{ Pathos } & $\mathrm{N}$ & 44 & 99 & 143 & & & \\
\hline & & $\%$ & 35,2 & 27,2 & 29,2 & & & \\
\hline & \multirow{2}{*}{ Logos } & $\mathrm{N}$ & 70 & 229 & 299 & & & \\
\hline & & $\%$ & 56,0 & 62,9 & 61,1 & & & \\
\hline \multirow{6}{*}{ 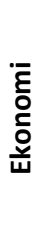 } & \multirow{2}{*}{ Ethos } & $\mathrm{N}$ & 11 & 54 & 65 & \multirow{6}{*}{4,015} & \multirow{6}{*}{2} & \multirow{6}{*}{ 134 } \\
\hline & & $\%$ & 7,3 & 13,3 & 11,6 & & & \\
\hline & \multirow{2}{*}{ Pathos } & $\mathrm{N}$ & 50 & 119 & 169 & & & \\
\hline & & $\%$ & 33,1 & 29,2 & 30,3 & & & \\
\hline & \multirow{2}{*}{ Logos } & $\mathrm{N}$ & 90 & 234 & 324 & & & \\
\hline & & $\%$ & 59,6 & 57,5 & 58,1 & & & \\
\hline \multirow{6}{*}{ :ᄒֻ } & \multirow{2}{*}{ Ethos } & $\mathrm{N}$ & 28 & 17 & 45 & \multirow{6}{*}{15,026} & \multirow{6}{*}{2} & \multirow{6}{*}{,001 } \\
\hline & & $\%$ & 22,6 & 9,7 & 15,0 & & & \\
\hline & \multirow{2}{*}{ Pathos } & $\mathrm{N}$ & 54 & 65 & 119 & & & \\
\hline & & $\%$ & 43,5 & 36,9 & 39,7 & & & \\
\hline & \multirow{2}{*}{ Logos } & $\mathrm{N}$ & 42 & 94 & 136 & & & \\
\hline & & $\%$ & 33,9 & 53,4 & 45,3 & & & \\
\hline \multirow{4}{*}{$\begin{array}{l}\frac{\varepsilon}{\pi} \\
\frac{\pi}{0} \\
\frac{0}{\circ}\end{array}$} & \multirow{2}{*}{ Ethos } & $\mathrm{N}$ & 50 & 107 & 157 & \multirow{4}{*}{8,251} & \multirow{4}{*}{2} & \multirow{4}{*}{,016 } \\
\hline & & $\%$ & 12,5 & 11,3 & 11,7 & & & \\
\hline & \multirow{2}{*}{ Pathos } & $\mathrm{N}$ & 148 & 283 & 431 & & & \\
\hline & & $\%$ & 37,0 & 29,9 & 32,0 & & & \\
\hline
\end{tabular}




\begin{tabular}{|l|l|l|l|l|l|l|l|l|}
\hline \multirow{2}{*}{ Logos } & $\mathrm{N}$ & 202 & 557 & 759 & & & \\
\cline { 3 - 6 } & $\%$ & 50,5 & 58,8 & 56,3 & & & \\
\hline
\end{tabular}

Çalışmada, iktidar ve ana muhalefet liderlerinin konuşmalarındaki ikna bileşenlerini kullanma yoğunluklarının karşılaştırılması, her iki liderin konuşmalarında ele aldığı ortak temalar olan diş politika, terör ve ekonomi üzerinden yapılmıştır (Tablo 3). Başkanlık temasında iktidar liderinin, selamlama ve kutlama temasında ise ana muhalefet liderinin itemlerin azlığından dolayı bu iki boyut karşılaştırmada değerlendirme dışı bırakılmıştır.

İktidar ve ana muhalefet liderlerinin grup konuşmalarında ortak ele aldıkları temaların ikna bileşenleri bağlamında analizinde dış politika ve ekonomi temalarında anlamlı bir ilişki bulunmazken ( $>0.05)$, terör temasında anlamlı bir ilişki bulunmuştur ( $\mathrm{x} 2=15,026 ; \mathrm{p}<0.01)$. Buna göre, terör temasında ethos ve pathos ikna bileşenlerinde iktidar partisi lideri ana muhalefet liderine göre daha yoğun bir kullanım sergilerken; logos ikna bileşeninde ana muhalefet liderinin iktidar partisi liderine göre daha yoğun bir kullanım sergilediği görülmektedir. Öte yandan iktidar ve ana muhalefet liderlerinin üzerinde durdukları tüm ortak temalar birlikte ele alındığında kullandıkları ikna bileşenleri bağlamında anlamlı bir ilişki bulunmuştur $(\mathrm{x} 2=8,251 ; \mathrm{p}<0.05)$. Buna göre, ethos ve pathos ikna bileşenlerinde iktidar partisi liderinin ana muhalefet liderine göre daha yoğun bir kullanım sergilediği görülmektedir. Logos ikna bileşeninde ise ana muhalefet liderinin iktidar partisi liderine göre daha yoğun bir kullanım sergilediği tespit edilmiştir.

Yukarıdaki tablolarda yer alan veriler değerlendirildiğinde, iktidar partisi liderinin kaynağın güvenilirliği ve duygusal çekicilikler ikna bileşenlerini kullanma yoğunluğunun nedeni olarak, parti grup konuşmalarında yaptığı icraatlara atıfta bulunması ve milli manevi değerleri referans alması söylenebilir. Öte yandan ana muhalefet liderinin rasyonel çekicilikler ikna bileşenini yoğun kullanma nedeni olarak, özellikle ekonomi ve dış politika temalarında sorular yönelterek dinleyicileri yönlendirmesi ve geçmiş politikalarla günümüz politikaları arasında mukayeseli anlatıma yoğun yer vermesi gösterilebilir.

\section{Sonuç ve Öneriler}


Çalışmanın teorik bölümünde çerçevesi çizilen retorik ikna bileşenlerin, siyasi liderlerin konuşmalarında farklı yoğunluklarda kullanılması söz konusudur. $\mathrm{Bu}$ farklı kullanım yoğunlukları konuşmada ele alınan temalara, siyasi liderlerin konuları ifade etme tarzlarına, temalar içerisinde yer alan özel konuların gündemdeki önem derecesine ve iktidar veya muhalefette olmaya göre değişebilmektedir.

$\mathrm{Bu}$ çalışma, iktidar ve ana muhalefet liderlerinin konuşmalarında ele aldıkları temalara göre ikna bileșenlerinden hangilerini daha yoğun kullandiğından hareket ederek ikna stratejilerini tespit etmeye imkân sunmakta ve ortak ele aldıkları temalar üzerinden ikna bileşenlerinin kullanımı bağlamında liderlerin konuşmalarının karşılaştırmasına olanak sağlamaktadır.

Araştırma sonucunda liderlerin TBMM grup konuşmalarında benzer temalara değindikleri, ancak temaların konuşmanın genelindeki ağırlık oranının farklı düzeylerde gerçekleştiği görülmüştür. Ana muhalefet lideri daha çok dış politika ve ekonomi temalarında rasyonel çekicilik bileşeni kapsamında değerlendirilecek cümleler ile konuşmasını yapmakta ve bunu ekseriyetle soru cümleleri kurarak gerçekleştirmektedir. İktidar partisi lideri ise terör, dış politika, ekonomi, icraat ve partiyi yüceltme temalarına neredeyse eşit oranlarda değinmektedir. Ekonomi ve dış politikada ağırlıkla rasyonel çekicilik, terör ile icraat ve partiyi yüceltme temalarında ise çoğunlukla duygusal çekicilik ikna bileşenli cümleler ile konuşmasını yapmaktadır. Ekonomi temasında, rasyonel çekicilik ikna bileşeninin daha çok iktidar olmadan önceki dönemlerle mevcut dönemin mukayeseli anlatımını sağlayan cümleler ile kullanıldığı görülmektedir. İcraat ve partiyi yüceltme temasında ise duygusal çekicilik ikna bileşeni yoğunlukla kullanılmaktadır. Bunun nedeni ise, uygulamaya konulan yeniliklerin, sonuçlandırılan projelerin başarısını, önemini ve gururunu yansıtan cümlelerin coşkulu üslupla aktarılmasından kaynaklanmaktadır.

Yine çalışmada liderlerin ele aldıkları ortak temalar üzerinde kullandıkları ikna bileşenleri bağlamında bir ilişkinin varlığı tespit edilmiştir. Dış politika, ekonomi ve terör ortak temalarında ana muhalefet lideri logos iktidar partisi lideri ise ethos ve pathos ikna bileşenlerini daha yoğun kullanmaktadır. 
Çalışmada, liderlerin konuşmalarında farklılık arz eden temalara bakıldığında, iktidar liderinin konuşmalarında icraat ve partiyi yüceltme ile yasama faaliyetleri temalarının, ana muhalefet liderinin konuşmalarında ise yönetim ve liyakat ile öğrenci olayları temalarınının ayrımlılığı ortaya çıkarttığı görülmektedir. Ayrımlılık gösteren temalar değerlendirildiğinde, özellikle icraat ve partiyi yüceltme teması, iktidarda olmayla; yönetim ve liyakat teması ise muhalefette olmayla bağlantılı bulunmuştur. Neticede, iktidarda ya da muhalefette olmak, işlenecek temaları değiştirmekte, dolayısıyla da liderlerin konuşmalarında kullanacakları ikna bileşenlerinin yoğunluklarını etkileyen bir faktör olarak tespit edilmektedir.

Ayrıca liderlerin üslupları açısından ikna bileşenleri değerlendirildiğinde, özellikle logos ikna bileşenli cümleler analiz edildiğinde, iktidar partisi liderinin cümlelerinde neden sonuç bildiren bağlaçlardaki kullanım fazlalığı; ana muhalefet liderinin konuşmalarında ise soru-cevap cümlelerinin kullanım fazlalığı saptanmıştır. $\mathrm{Bu}$ durumda, logos ikna bileşeni, iktidar partisi liderince yoğun olarak neden sonuç bildiren bağlaçlarla tesis edilirken; ana muhalefet lideri ise bu bileşeni yoğunlukla soru- cevap cümleleri ile gerçekleştirme eğilimindedir. $\mathrm{Bu}$ eğilimden hareketle, liderlerin sahip oldukları üsluplarının onların konuşmalarındaki ikna bileşenlerinin kurgulanmasını etkilemesinden bahsedilebilir.

Kısaca çalışma, giriş bölümünde belirtilen araştırma sorularına yanıt verebilmektedir. Buna göre, liderlerin ele aldıkları konulara göre kullandıkları ikna bileşenleri farklılaşmaktadır. İktidarda ve muhalefette olma durumu, ele alınan temaları belirlemekte böylelikle ikna bileşenlerinin yoğunluğunu değiştirmektedir. Liderlerin ele aldığı ortak temalarda ise ikna bileşenlerinin yoğunluğu değişmektedir. Son olarak, liderlerin sahip olduğu üslupla bağlantılı olarak aynı ikna bileşeni faklı cümle kurgularıyla tesis edilebilmektedir.

Çalışma liderlerin yalnızca Haziran 2016' da gerçekleştirdikleri TBMM grup konuşmaları üzerinden elde edilen verilerle sınırlı olması münasebetiyle kısa bir döneme yönelik değerlendirme imkânı vermektedir. Bu nedenle sonraki çalışmalarda siyasi liderlerin daha uzun döneme yayılan grup konuşmaları söz konusu ikna bileşenleri bağlamında ele alınıp değerlendirilirse, daha farklı sonuçlara ulaşılabilir 
ve liderlerin ikna bileşenleri kullanma alışkanlıkları noktasında özgün değeri daha yüksek sonuçlar elde edilebilir.

\section{KAYNAKÇA}

AKYÜZ, Ünal (2009). “Siyaset ve Ahlak”, Yasama Dergisi, 11, s. 93-129.

ANIK, Cengiz (2000). Siyasal İkna, Ankara: Vadi Yayınları.

ARISTOTALES (2008). Retorik. (Çev: Mehmet H. Doğan), İstanbul: Yapı Kredi Yayıncilik.

ARKLAN, Ümit (2006). "Siyasal Liderlikte Karizma Olgusu: Recep Tayyip Erdoğan Örneğinde Teorik ve Uygulamalı Bir Çalışma”, Selçuk Üniversitesi Sosyal Bilimler Enstitüsü Dergisi, 16, 45-65.

BALCI, Şükrü (2003). "Politik Kampanyalarda İmaj Yönetimi (Genç Parti Örneği)”, Selçuk Üniversitesi Sosyal Bilimler Enstitüsü Dergisi, 9, 143-162.

BARUT, Basri, ve ALTUNDAĞ, C. Sinan (2005). "Globalleşen Dünyada Bir Siyasal İkna Unsuru Olarak Vaatler (3 Kasım 2002 Türkiye Milletvekili Genel Seçimleri İle 2 Kasım 2004 ABD Başkanlık Seçimleri Karşılaştırmalı Örneğiyle)”, Selçuk Üniversitesi İletişim Fakültesi Dergisi, 4 (1), 80-90.

BAŞARIR, Murat (2015). Siyasal İletişim Sürecinde Lider Üslubunun Seçmen Davranışlarındaki Rolü Üzerine Bir Araştırma, Yayınlanmamış Doktora Tezi, Konya.

CATELlANI, Patrizia; BERTOLOTTI, Maura; COVELli, Venusia (2013). Counterfactual Communication in Politics: Features and Effects on Voters. In Multimodal Communication in Political Speech (Eds), Isabella Poggi, 75-84. Berlin: Springer-verlag.

ÇADIRCI, Ahmet (2010). "Retorik-Aristotales”, Hukuk Gündemi Dergisi, 1, s. 9097.

DAMLAPINAR, Zülfikar ve BALCI, Şükrü (2014). Siyasal İletişim Sürecinde Seçimler, Adaylar, İmajlar, İstanbul: Literatürk. 
DOĞAN, Adem ve GÖKER, Göksel (2013). Siyasal İletişim Araştırmaları, Ankara: Nobel Yayınları.

ERDOĞAN, İrfan (1997). İletişim, Egemenlik, Mücadeleye Giriş, Ankara: İmge Kitabevi.

FİDAN, Mehmet (2000). Siyasette Güvenilirlik İmaj1, Konya: S.Ü. İletişim Fakültesi Yayınları.

GÖKÇE, Orhan (1993). İletişim Bilimine Giriş, Ankara: Adalet Matbaası.

GÜNGÖR, Nafize (2011). İletişim Kuramlar Yaklaşımlar, Ankara: Siyasal Kitabevi.

JAMIESON, Harry (1996). İletişim ve İkna, (Çev: Nejdet Atabek ve Banu Dağtaş), Eskişehir: Anadolu Üniversitesi Yayınları.

KALENDER, Ahmet (2005). Siyasal İletişim Seçmenler ve İkna Stratejileri, Konya: Çizgi Kitabevi.

KÖKER, Eser (2007). Politikanın İletişimi İletişimin Politikası, Ankara: İmge Kitabevi.

KROSTENKO, Brian A. (2004). "Text and Context in the Roman Forum: The Case of Cicero's First Catilinarian 1." (Eds), Walter Jost and Wendy Olmsted, in a Companion to Rhetoric And Rhetorical Criticism, Blackwell Publishing, 3857.

LAUER, Janice M. (2004). Invention in Rhetoric and Composition, USA: Parlor Press.

LILLEKER, Darren G. (2013). Siyasal İletişim Temel Kavramlar, (Çev: Tolga Sağlam), İstanbul: TíMAŞ Yayınları.

MEYER, Michel (2009). Retorik, Ankara: Dost Kitabevi.

ÖZKAN, Abdullah (2004), Siyasal İletişim, İstanbul: Nesil Yayınları.

POLAT, Veli (2008). Politik Konuşma ve Politik Söylenme, İstanbul: Derin Yayınlar1.

ROSKIN, Micheal G; CORD, Robert L; MEDEIROS, James A.; JONES, Walter S. (2013). Siyaset Bilimi, (Çev: Atilla Yayla), Ankara: Adres Yayınları. 
TAŞCIOĞLU, Raci (2007). Seçim Kampanyalarındaki Dönüşüm. 'Amerikanlaşma' Bağlamında 3 Kasım 2002 Genel Seçimlerinde Genç Parti Seçim Kampanyası, A.Ü. Sosyal Bilimler Enstitüsü Yayınlanmamış Doktora Tezi, Ankara

TEPEBAŞILI, Fatih (2016). Retorik Konuşma Sanatı Söz Bilimi, Konya: Çizgi Kitabevi.

TÜRKÖNE, Mümtaz'er (2014). Siyaset, İstanbul: Etkileşim Yayınları.

ULAŞ, Sarp E. (2002). Felsefe Sözlüğü, Ankara: Bilim ve Sanat Yayınları.

UZUN, Ertuğrul (2015). "Platon'da Retorik'in Peşinde Bir Phaidros Okuması" Hukuk Kuramı, 2 (2), 28-34.

YAVAŞGEL, Emine (2004). Siyasal İletişim Kavramlar ve Ardındakiler, Ankara: Babil Yayın Dağıtım.

YILMAZ, R. Ayhan (2007). İkna Edici İletişim, (Editör), N. Aysun Yüksel, İletişim Bilgisi, Eskişehir: AÖF Yayınları Yayın No: 909, 183-197.

YÜKSEL, A. Haluk (1994). İkna Edici İletişim. Eskişehir: Anadolu Üniversitesi Yayınları.

YÜKSEL, A. Haluk (2005). İkna ve Konuşma, Eskişehir: Anadolu Üniversitesi Yayınları. 